\title{
EKSPEKTASI PEMBELAJARAN BERBASIS KURIKULUM: STUDI KASUS PENGAJARAN MATA KULIAH METODE PENELITIAN PADA PROGRAM STUDI ILMU HADIS
}

\author{
Wahyudin Darmalaksana \\ Jurusan Ilmu Hadis, Fakultas Ushuluddin, UIN Sunan Gunung Djati Bandung \\ Email: yudi_darma@uinsgd.ac.id
}

\begin{abstract}
This study aims to discuss curriculum-based learning expectations for the achievement of excellence in higher education. This research method uses a qualitative type through literature study and field studies with case studies in teaching Research Methods in the Department of Hadith, Faculty of Ushuluddin UIN Sunan Gunung Djati Bandung. The results and discussion of this study include learning evaluation, course outcomes based on learning planning, and the learning process. The conclusion of this study is that hard work to exceed the expectations of standardized curriculum-based learning is the main sequence for the achievement of excellence in higher education. This study recommends the urgency of preparing a curriculum with measurable expectations in order to realize the excellence of higher education at the national level towards excellence at the international level.
\end{abstract}

Keywords: learning outcomes, learning evaluation, learning planning, learning process

\begin{abstract}
ABSTRAK
Penelitian ini bertujuan membahas ekspektasi pembelajaran berbasis kurikulum bagi pencapaian keunggulan pendidikan tinggi. Metode penelitian ini menggunakan jenis kualitatif melalui studi pustaka dan studi lapangan dengan studi kasus pada pengajaran mata kuliah Metode Penelitian di Jurusan Ilmu Hadis Fakultas Ushuluddin UIN Sunan Gunung Djati Bandung. Hasil dan pembahasan penelitian ini mencakup evaluasi pembelajaran, capaian mata kuliah berbasis perencanaan pembelajaran, dan proses pembelajaran. Kesimpulan penelitian ini adalah kerja keras melampaui ekspektasi pembelajaran berbasis kurikulum yang terstandar menjadi urutan paling utama bagi pencapaian keunggulan pendidikan tinggi. Penelitian ini merekomendasikan urgensi penyusunan kurikulum dengan ekspektasi yang terukur dalam rangka mewujudkan keunggulan pendidikan tinggi di tingkat nasional menuju keunggulan di level internasional.
\end{abstract}

Kata Kunci: Capaian pembelajaran, Evaluasi pembelajaran, Perencanaan pembelajaran, Proses pembelajaran

\section{PENDAHULUAN}

Keunggulan pendidikan tinggi dilihat dari pencapaian kurikulum. Secara umum kurikulum dipahami sebagai seperangkat rencana dan pengaturan mengenai tujuan, isi, dan bahan pelajaran serta cara yang digunakan sebagai pedoman penyelenggaraan kegiatan pembelajaran untuk mencapai tujuan pendidikan (Herianto, 2020). Di dalam kurikulum ada rencana dan tujuan (Aprilia, 2020) yang dibebankan pada mata kuliah (Fadillah, 2019). Jika suatu mata kuliah telah memenuhi capaian pembelajaran sesuai tujuan pendidikan yang ditetapkan di dalam kurikulum, maka mata kuliah tersebut disebut telah menopang keunggulan pendidikan tinggi.

* Copyright (c) 2020 Wahyudin Darmalaksana

This work is licensed under a Creative Commons Attribution-ShareAlike 4.0 International License. 
Khazanah Pendidikan Islam, Vol. 2 No. 3: 114-125

Ekspektasi Pembelajaran Berbasis Kurikulum: Studi Kasus Pengajaran Mata Kuliah Metode Penelitian Pada Program Studi Ilmu Hadis

Wahyudin Darmalaksana

Pendidikan tinggi di Indonesia diarahkan menjadi pusat keunggulan (excellence) bertaraf internasional (Fachriansyah \& Sulastri, 2020). Ini berarti pendidikan tinggi mendapat tantangan untuk menerapkan standar penjaminan mutu internasional minimal Asia (Istikaroh, 2020). Arah kebijakan ini menuntut pendidikan tinggi memiliki ekspektasi, yaitu suatu harapan atau keyakinan yang diharapkan akan menjadi kenyataan di masa depan sesuai dengan keinginan dimana untuk mencapainya harus dengan tindakan nyata (Istislami, 2020). Secara operasional ekspektasi disebut input berupa visi, misi, dan tujuan yang ingin dicapai (Istislami, 2020). Pada tataran ini, pendidikan tinggi di Indonesia terus bekerja keras merumuskan ekspektasi menuju world class university (WCU) dengan tantangan keunggulan (Rizky, 2019).

Ide menuju standar internasional pendidikan tinggi ditempuh dengan cara melampaui keunggulan di tingkat nasional. Pemerintah Indonesia telah menetapkan kebijakan kurikulum pendidikan tinggi (Susanti, 2020). Pada panduan penyusunan kurikulum pendidikan tinggi telah ditetapkan ketentuan pendidikan tinggi untuk mencantumkan ekspektasi mencakup visi, standar kompetensi lulusan (SKL), capaian pembelajaran lulusan (CPL), profil lulusan, rencana pembelajaran, proses pembelajaran, capaiaan mata kuliah, dan evaluasi pembelajaran (Penyusun, 2018a). Sejalan dengan ini, Direktorat Pendidikan Tinggi Keagamaan Islam (Diktis), Direktorat Jenderal Pendidikan Islam (Ditjen Pendis), Kementerian Agama Republik Indonesia, telah menetapkan panduan pengembangan kurikulum untuk lingkungan Perguruan Tinggi Keagamaan Islam (PTKI) dengan ketetapan secara mengikat bagi seluruh program studi (prodi) atau jurusan berupa standar kompetensi lulusan, SKL, capaian pembelajaran lulusan, CPL, dan profil lulusan (Penyusun, 2018b).

Pendidikan tinggi Indonesia mendapat tantangan untuk melampaui standar nasional pendidikan menuju WCU. Ini berarti diawali dengan penerapan standar nasional pendidikan tinggi. Seluruh jurusan di lingkungan PTKI dituntut menerapkan standar kompetensi lulusan, SKL, capaian pembelajaran lulusan, $\mathrm{CPL}$, dan profil lulusan (Penyusun, 2018b). Berbasis pada panduan ini, jurusan dituntut menyusun visi, misi, tujuan (Penyusun, 2018a), rencana pembelajaran, proses pembelajaran, capaiaan mata kuliah, dan evaluasi pembelajaran (Penyusun, 2018a). Tegaslah bahwa jika suatu mata kuliah telah memenuhi capaian ekspektasi pembelajaran sesuai tujuan pendidikan yang ditetapkan di dalam kurikulum, maka mata kuliah tersebut disebut telah menopang keunggulan pendidikan tinggi.

Berdasarkan paparan di atas, formula penelitian ini meliputi rumusan masalah, pertanyaan penelitian, dan tujuan penelitian (Darmalaksana, 2020b). Rumusan masalah penelitian ini adalah terdapat ekspektasi pembelajaran untuk mencapai sasaran keunggulan. Pertanyaan penelitian ini ialah bagaimana ekspektasi pembelajaran untuk mencapai sasaran keunggulan. Tujuan penelitian ini yaitu membahas ekspektasi pembelajaran untuk mencapai sasaran keunggulan. Penelitian ini diharapkan memiliki implikasi manfaat khususnya bagi sejawat para pengampu mata kuliah dalam penyusunan ekspektasi pembelajaran untuk pencapaian sasaran keunggulan.

\section{METODE PENELITIAN}

Metode penelitian menerapkan jenis kualitatif melalui studi pustaka dan studi lapangan (Darmalaksana, 2020j) dengan praktik pengajaran pada pembelajaran mata kuliah Metode Penelitian di Semester IV Kelas A dan Kelas B jenjang Sarjana Jurusan Ilmu Hadis Fakultas Ushuluddin UIN Sunan Gunung Djati Bandung Tahun Ajaran 2019-2020. 


\section{Khazanah Pendidikan Islam, Vol. 2 No. 3: 114-125}

Ekspektasi Pembelajaran Berbasis Kurikulum: Studi Kasus Pengajaran Mata Kuliah Metode Penelitian Pada Program Studi Ilmu Hadis

Wahyudin Darmalaksana

\section{HASIL DAN PEMBAHASAN}

\section{Evalusi Pembelajaran}

Bagian ini menampilkan evaluasi pembelajaran mata kuliah Metode Penelitian di Semester IV Kelas A dan Kelas B jenjang Sarjana pada Jurusan Ilmu Hadis Fakultas Ushuluddin UIN Sunan Gunung Djati Bandung Tahun Ajaran 2019-2020.

Tabel 1. Nilai Kelas A

\begin{tabular}{cccl} 
No. & Nilai & Jumlah & Keterangan \\
\hline 1 & A & 26 & 9 Perempuan, 17 Laki-laki \\
\hline 2 & B & 3 & 3 Laki-laki \\
\hline 3 & C & 6 & 6 Laki-laki \\
\hline 4 & D & 0 & 0 \\
\hline 5 & E & 0 & 0 \\
\hline
\end{tabular}

Pada Tabel 1, jumlah Kelas A sebanyak 35 Mahasiswa dengan komposisi 9 Perempuan dan 26 Lakilaki. Nilai A sebanyak 26 Orang dengan komposisi 9 Perempuan dan 17 Laki-laki. Nilai B sebanyak 3 Orang semua laki-laki. Nilai C sebanyak 6 Orang semua laki-laki. Nilai D dan E kosong,.

Tabel 2. Nilai Kelas B

\begin{tabular}{cccc} 
No. & Nilai & Jumlah & Keterangan \\
\hline 1 & A & 21 & 15 Perempuan, 6 Laki-laki \\
\hline 2 & B & 14 & 12 Laki-laki, 2 Perempuan \\
\hline 3 & C & 5 & 4 Laki-laki, 1 Perempuan \\
\hline 4 & D & 0 & 0 \\
\hline 5 & E & 0 & 0 \\
\hline
\end{tabular}

Pada Tabel 2, jumlah Kelas B sebanyak 40 Mahasiswa dengan komposisi 18 Perempuan dan 22 Laki-laki. Nilai A sebanyak 21 Orang dengan komposisi 15 Perempuan dan 6 Laki-laki. Nilai B sebanyak 14 Orang dengan komposisi 12 Laki-laki dan 2 Perempuan. Nilai C sebanyak 5 Orang dengan komposisi 4 Laki-laki dan 1 Perempuan. Nilai D dan E kosong. 
Khazanah Pendidikan Islam, Vol. 2 No. 3: 114-125

Ekspektasi Pembelajaran Berbasis Kurikulum: Studi Kasus Pengajaran Mata Kuliah Metode Penelitian Pada Program Studi Ilmu Hadis

Wahyudin Darmalaksana

Tabel 3. Total Nilai Kelas A dan B

\begin{tabular}{cccc} 
No. & Nilai & Jumlah & Keterangan \\
\hline 1 & A & 47 & 24 Perempuan, 23 Laki-laki \\
\hline 2 & B & 17 & 15 Laki-laki, 2 Perempuan \\
\hline 3 & C & 11 & 10 Laki-laki, 1 Perempuan \\
\hline 4 & D & 0 & 0 \\
\hline 5 & E & 0 & 0 \\
\hline
\end{tabular}

Pada Tabel 3, jumlah Kelas A dan B sebanyak 75 Mahasiswa dengan komposisi 27 Perempuan dan 48 Laki-laki. Nilai A sebanyak 47 Orang dengan komposisi 24 Perempuan dan 23 Laki-laki. Nilai B sebanyak 17 Orang dengan komposisi 15 Laki-laki dan 2 Perempuan. Nilai C sebanyak 11 Orang dengan komposisi 10 Laki-laki dan 1 Perempuan. Nilai D dan E kosong.

\section{Capaian Mata Kuliah}

Bagian ini memaparkan capaian mata kuliah Metode Penelitian di Semester IV Kelas A dan Kelas B jenjang Sarjana pada Jurusan Ilmu Hadis Fakultas Ushuluddin UIN Sunan Gunung Djati Bandung Tahun Ajaran 2019-202o. Adapun capaian mata kuliah di bawah ini:

1. Buku panduan cara menulis proposal ber-ISBN (International Standard Book Number) dan sertifikat Hak Kekayaan Intelektual (HKI) dalam bentuk Hak Cipta (Darmalaksana, 2020o);

2. Buku kompilasi proposal ber-ISBN dan sertifikat HKI (Qintan et al., 2020);

3. Buku rekam jejak perkuliahan ber-ISBN dan sertifikat HKI (Darmalaksana, 2020k);

4. Buku kompilasi artikel hasil perkuliahn ber-ISBN dan sertifikat HKI; dan

5. Artikel ilmiah mahasiswa 1 (satu) judul pada jurnal ilmiah ber-ISSN terakreditasi nasional index Sinta dan sertifikat HKI (Awaliyah \& Darmalaksana, 2020).

\section{Visi, Misi, dan Profil Lulusan Jurusan Ilmu Hadis}

Visi Jurusan Ilmu Hadis jenjang Sarjana Fakultas Ushuluddin UIN Sunan Gunung Djati Bandung, yaitu mewujudkan program studi hadis yang unggul dan kompetitif di level regional berbasis Wahyu Memandu Ilmu dalam bingkai akhlakul karimah (Penyusun, 2020). Adapun misi jurusan ini, yaitu: 1) Menciptakan budaya akademik yang moderat dan terintegrasi berdasarkan nilai-nilai keislaman dan keindonesiaan; 2) Menyelenggarakan tridharma perguruan tinggi yang bermutu dan relevan dengan kebutuhan nasional dan tantangan global berbasis wahyu memandu ilmu; dan 3) Menciptakan lulusan yang berdaya saing secara nasional dan global, bertakwa serta berakhlak mulia (Penyusun, 2020).

Profil lulusan jurusan ini, yakni: 1) Ahli hadis pemula; 2) Akademisi bidang hadis; dan 3) Asisten peneliti hadis dan sosial keagamaan (Tim Penyusun, 2018). Deskripsi ahli hadis pemula adalah sarjana agama yang berkepribadian baik, berpengetahuan luas dan mutakhir serta mampu mampu 
Khazanah Pendidikan Islam, Vol. 2 No. 3: 114-125

Ekspektasi Pembelajaran Berbasis Kurikulum: Studi Kasus Pengajaran Mata Kuliah Metode Penelitian Pada Program Studi Ilmu Hadis

Wahyudin Darmalaksana

menerjemahkan dan menyajikan kandungan hadis untuk pengembangan dan penyiaran ajaran Islam yang moderat dan toleran (Islam rahmatan lil 'aalamin) dalam kehidupan sosial keagamaan yang multi agama, kebangsaan dan kenegaraan berdasarkan keilmuan, keahlian, dan sikap yang sesuai dengan prinsip-prinsip keislaman (Tim Penyusun, 2018).

Deskripsi akademisi bidang hadis adalah sarjana agama yang berkpribadian baik, memiliki kemampuan kerja, penguasaan pengetahuan, kemampuan manajerial dan tanggung jawab sebagai akademisi atau ahli bidang hadis dan ilmu hadis dalam pengembangan ajaran Islam yang moderat dan toleran dalam kehidupan sosial keagamaan yang multi agama, kebangsaan dan kenegaraan berdasarkan keilmuan, keahlian, dan sikap yang sesuai dengan prinsip-prinsip keislaman (Tim Penyusun, 2018).

Deskripsi asisten peneliti hadis dan sosial keagamaan adalah sarjana agama sebagai asisten peneliti yang berkepribadian baik, berpengetahuan luas dan mutakhir serta mampu melaksanakan penelitian dan pengkajian di bidang hadis \& pengembangan Ilmu hadis, mampu menerjemahkan dan menyajikan kandungan hadis untuk pengembangan ajaran Islam yang moderat dan toleran dalam kehidupan sosial keagamaan yang multi agama, kebangsaan dan kenegaraan berdasarkan keilmuan, keahlian, dan sikap yang sesuai dengan prinsip-prinsip keislaman. berdasarkan keilmuan, keahlian, dan sikap yang sesuai dengan prinsip-prinsip keislaman (Tim Penyusun, 2018).

\section{SKL dan CPL pada Mata Kuliah Metode Penelitian}

Standar kompetensi lulusan, SKL, merujuk pada kerangka kualifikasi nasional Indonesia, KKNI, sedangkan capaian pembelajaran lulusan, CPL, jenjang Sarjana Jurusan Ilmu Hadis telah ditetapkan secara baku (Tim Penyusun, 2018). Adapun CPL mata kuliah Metode Penelitian pada tabel 4.

Tabel 4. Capaian Pembelajaran Lulusan

CPL SKL Mengacu KKNI

\begin{tabular}{|c|c|}
\hline $\begin{array}{l}\text { CPL Bidang Sikap } \\
\text { dan tata nilai }(S)\end{array}$ & $\begin{array}{l}\text { 1. Menghargai keanekaragaman budaya, pandangan, agama dan } \\
\text { kepercayaan serta pendapat atau temuan rasional orang lain (S.5); } \\
\text { 2. Menunjukkan sikap bertanggung jawab atas pekerjaan di bidang } \\
\text { keahlianya secara mandiri (S.9). }\end{array}$ \\
\hline $\begin{array}{l}\text { CPL Bidang } \\
\text { Penguasaan } \\
\text { Pengetahuan (P) }\end{array}$ & $\begin{array}{l}\text { 1. Menguasai pengetahuan dan langkah-langkah dalam mengembangkan } \\
\text { pemikiran kritis, logis, kreatif, inovatif, dan sistematis serta memiliki } \\
\text { keingintahuan intelektual untuk memecahkan masalah pada tingkat } \\
\text { individual dan kelompok dalam komunitas akademik dan non akademik } \\
\text { (P.4); } \\
\text { 2. Menguasai hadis, berbagai teori dalam ilmu hadis, berbagai metodologi } \\
\text { kajian hadis dan sejarah Ilmu hadis dari masa ke masa (P.8); } \\
\text { 3. Menguasai cabang-cabang ilmu modern yang dapat digunakan dalam } \\
\text { pemahaman hadis (P.12). }\end{array}$ \\
\hline $\begin{array}{l}\text { CPL Bidang } \\
\text { Ketrampilan Umum } \\
(\mathrm{KU})\end{array}$ & $\begin{array}{l}\text { 1. Mampu menunjukkan kinerja mandiri, bermutu dan terukur (KU.2); } \\
\text { 2. Mampu mendokumentasikan, menyimpan, mengamanahkan, dan } \\
\text { menemukan kembali data untuk menjamin kesahihan mencegah plagiasi } \\
\text { (KU.9); } \\
\text { 3. Menunjukkan kemampuan literasi informasi, media dan memanfaatkan } \\
\text { teknologi informasi dan komunikasi untuk pengembangan keilmuan dan } \\
\text { kemampuan kerja (KU.10); }\end{array}$ \\
\hline CPL Bidang & $\begin{array}{l}\text { 1. Mampu mendokumentasikan hadis secara digital berbasis } \\
\text { perkembangan ilmu pengetahuan dan teknologi informatika (KK.2); }\end{array}$ \\
\hline
\end{tabular}




\section{Khazanah Pendidikan Islam, Vol. 2 No. 3: 114-125}

Ekspektasi Pembelajaran Berbasis Kurikulum: Studi Kasus Pengajaran Mata Kuliah Metode Penelitian Pada Program Studi Ilmu Hadis

Wahyudin Darmalaksana

Ketrampilan Khusus

(KK)
2. Mampu memahami makna hadis dan kandungannya secara kontekstual dalam kehidupan sosial keagamaan, kebangsaan dan kenegaraan (KK.4);

3. Mampu menyebarluaskan hadis dan kandungannya kepada masyarakat dalam kehidupan sosial keagamaan, kebangsaan dan kenegaraan (KK.7).

Capaian pembelajaran mata kuliah, CPMK, Metode Penelitian diarahkan untuk memenuhi Profil Lulusan, yaitu sebagai Asisten Peneliti Hadis dan Sosial Keagamaan, dan untuk berkontribusi pada CPL Sikap dan tata nilai (S. 5 dan 9), pengetahuan (P. 4, 8, dan 12), dan keterampilan, baik umum (KU. 2, 9, dan 10) mupun khusus (KK. 2, 4, dan 7). Adapun outcome mata kuliah ini kompilasi proposal penelitian dalam bentuk buku ISBN.

Mata kuliah Metode Penelitian merupakan bagian dari mata kuliah komptensi utama jenjang Sarjana Jurusan Ilmu Hadis. Mata kuliah ini mencakup pembelajaran prkatis penyusunan proposal penelitian (Darmalaksana, 2020a, 2020m), latihan penelitian sederhana (mini research), dan penulisan hasil penelitian ke dalam bentuk artikel ilmiah (Darmalaksana, 2020c), termasuk latihan penggunaan aplikasi references (Darmalaksana, 2020l), cek plagiasi, paraphrase, pengiriman artikel ke jurnal ilmiah (Darmalaksana, 2020i), dan korespondensi digital (Darmalaksana \& Suryana, 2018) berbasis open journal system (OJS).

\section{Bahan Kajian dan Kriteria Penilaian}

Mata kuliah Metode Penelitian berbobot 2 SKS (Sistem Kredit Semester) dengan materi kajian dan bobot kedalaman di tabel 5 .

Tabel 5. Bahan Kajian dan Bobot Kedalaman

\begin{tabular}{clc}
\hline No. & Topik/Bahan -Kajian & Bobot \\
& & 2 \\
\hline 1 & Kontrak Belajar & 3 \\
\hline 2 & Penyusunan Rumusan dan Tujuan Penelitian & 3 \\
\hline 3 & Penelusuran Referensi dan Tinjauan Pustaka & 3 \\
\hline 4 & Penyusunan Kerangka Berpikir & 3 \\
\hline 5 & Menetapkan Metode Penelitian & 3 \\
\hline 6 & Penggunaan Aplikasi References & 3 \\
\hline 7 & Penyelesaian Proposal Penelitian & 3 \\
\hline 8 & Ujian Tengah Semester (UTS) & 3 \\
\hline 9 & Pendahuluan Mini Penelitian & \\
\hline
\end{tabular}


Khazanah Pendidikan Islam, Vol. 2 No. 3: 114-125

Ekspektasi Pembelajaran Berbasis Kurikulum: Studi Kasus Pengajaran Mata Kuliah Metode Penelitian Pada Program Studi Ilmu Hadis

Wahyudin Darmalaksana

\begin{tabular}{clc}
\hline \hline 10 & Pelaksanaan Mini Penelitian & 3 \\
\hline 11 & Hasil Penelitian & 3 \\
\hline 12 & Pembahasan & 3 \\
\hline 13 & Penarikan Kesimpulan & 3 \\
\hline 14 & Cek Plagiarism dan Paraphrase & 3 \\
\hline 15 & Submit paper dan korespondensi & 3 \\
\hline 16 & Ujian Akhir Semester (UAS) & 3
\end{tabular}

Waktu perkuliahan mata kuliah ini meliputi 1 jam pelajaran kali 50 menit kali jumlah SKS, 14 kali pertemuan per semester, 1 kali UTS dan 1 kali UAS. Adapun kriteria dan atau indeks penilaian mata kuliah Metode Penelitian ini di tabel 6.

Tabel 6. Kriteria atau Indeks Penilaian

Kriteria Penilaian

Penilaian

Rubrik/standar dan penilaian
1. Penilaian berdasarkan pencapaian kompetensi dengan mengacu pada pencapaian rerata kelompok belajar;

2. Kehadiran minimal $80 \%$ (untuk dapat mengikuti ujian).

1. Kegiatan kelas (30\%) mencakup aktifitas interaktif mahasiswa dalam dinamika kelas secara konstruktif dan kemampuan pengetahuan terhadap bahan kajian secara kritis;

2. Latihan penulisan (30\%) meliputi pelaksanaan latihan secara bertahap sejak perencanaan penelitian (proposal), pelaksanaan mini penelitian (mini research), dan penulisan hasil penelitian dalam bentuk artikel ilmiah tahapan sebagai latihan terstruktur. Pengiriman (submit) artikel ke jurnal ilmiah dan korespondensi sebagai kemajuan mandiri.

3. UTS (20\%) dan UAS (20\%)

1. Kegiatan kelas, yakni: 80-100: terlibat aktif dalam memberikan kontribusi signifikan terhadap pembelajaran; penguasaan bahan kajian secara kritis; dan pelaksanaan tahapan latihan penulisan secara kontinue; 60-79: terlibat aktif dalam memberikan kontribusi positif dalam pembelajaran; penguasaan bahan kajian tanpa pandangan yang kritis; dan pelaksanaan tahapan latihan penulisan tidak secara kontinue; 40-59: terlibat aktif dalam memberikan kontribusi yang cukup terhadap pembelajaran; pemahaman yang cukup tentang bahan kajian; dan pelaksanaan tidak secara bertahap; 20-39: tidak terlibat aktif dalam kegiatan kelas; penguasaan bahan kajian yang lemah; dan tidak konsultasi latihan penulisan; dan 0-19: tidak terlibat aktif, tidak konsultasi, dan tidak melaksanakan latihan penulisan;

2. Pelaporan progress penulisan artikel sampai pengiriman kejurnal ilmiah dan pelaksanaan korespondensi. 
Khazanah Pendidikan Islam, Vol. 2 No. 3: 114-125

Ekspektasi Pembelajaran Berbasis Kurikulum: Studi Kasus Pengajaran Mata Kuliah Metode Penelitian Pada Program Studi Ilmu Hadis

Wahyudin Darmalaksana

\begin{tabular}{|c|c|c|}
\hline $\begin{array}{l}\text { Praktek Mata Kuliah } \\
\text { dan outcome } \\
\text { Pembelajaran }\end{array}$ & 2. & $\begin{array}{l}\text { Praktek penulisan proposal penelitian, pelaksanaan mini research, } \\
\text { penulisan artikel ilmiah hasil penelitian, pengiriman (submit) } \\
\text { artikel ke jurnal ilmiah, dan pelaksanaan korespondensi dengan } \\
\text { publisher; } \\
\text { Praktek menghasilkan outcome minimal proposal yang } \\
\text { dikompilasi menjadi buku ISBN dan maksimal publikasi artikel } \\
\text { pada jurnal ilmiah ISSN serta Sertifikat Hak Kekayaan Intelektual } \\
\text { (HKI) berupa Hak Cipta. }\end{array}$ \\
\hline $\begin{array}{l}\text { UTS dan UAS } \\
\text { (pertanyaan terbuka) }\end{array}$ & $\begin{array}{l}3 . \\
4 . \\
5 .\end{array}$ & $\begin{array}{l}\text { Nilai A 80-100 merespon ujian dengan sempurna (tingkat } \\
\text { kesalahan data kurang dari 20\%), merujuk pada bahan kajian } \\
\text { secara kritis, melampirkan proposal hasil latihan, menunjukan } \\
\text { progress (kemajuan) penulisan artikel ilmiah, dan terdapat } \\
\text { forensic jejak digital submit artikel ke jurnal ilmiah serta } \\
\text { korespondensi dengan publisher; } \\
\text { Nilai B 60-79 merespon ujian dengan baik, merujuk bahan kajian; } \\
\text { melampirkan proposal hasil latihan tidak selaras dengan bahan } \\
\text { kajian, dan menunjukan progress (kemajuan) penulisan artikel } \\
\text { ilmiah tanpa proses feedback dalam rangka telaah peningkatan } \\
\text { kualitas penulisan; } \\
\text { Nilai C } 40-59 \text { merespon ujian dengan ketepatan } 40-50 \% \text { dan tidak } \\
\text { melampirkan proposal hasil latihan; } \\
\text { Nilai D 20-39 merespon ujian dengan tidak tepat hingga } 60 \% \text {; dan } \\
\text { E 0-19 tidak merespon ujian. }\end{array}$ \\
\hline
\end{tabular}

Sumber perkuliahan meliputi referensi, yaitu: Wahyudin Darmalaksana, 2020, Cara Menulis Proposal Penelitian, Bandung: Fakultas Ushuluddin UIN Sunan Gunung Djati (Darmalaksana, 2020o); Tim Penyusun, 2019, Pedoman Penulisan Skripsi, Tesis, dan Disertasi, Bandung: UIN Sunan Gunung Djati; Tim Penyusun, 2018, Panduan Penulisan Karya Ilmiah, Jakarta: Ristek Dikti Republik Indonesia; dan Wahyudin Darmalaksana, 2020, Kelas Menulis: Dari Proposal ke Penulisan Artikel sampai Publikasi di Jurnal Ilmiah, Bandung: Fakultas Ushuluddin UIN Sunan Gunung Djati (Darmalaksana, 2020g). Serta rujukan lain, seperti latihan efektif menulis (Darmalaksana, 2020e), penyusunan proposal penelitian (Darmalaksana, 2019), latihan menulis latarbelakang masalah (Darmalaksana, 2020h), bimbingan teknis penelitian (Darmalaksana, n.d.), dan artikel ilmiah capaian mata kuliah (Darmalaksana, 2020f).

\section{Proses Pembelajaran Berbasis Ekspektasi Menuju Keunggulan}

Bagian ini membahas proses pembelajaran berbasis ekspektasi menuju keunggulan. Perkulihan ini dilaksanakan secara online (Darmalaksana, 2020n) yang dilaksanakan mulai tanggal 16 Maret 2020 dan berakhir Senin, 13 Juli 2020 untuk Kelas A dan Rabu, 15 Juli 2020 untuk Kelas B. Kuliah online berlangsung disebabkan dampak Covid-19 (Telaumbanua, 2020). Telah dilaporkan bahwa kuliah online (daring) relatif tidak ada kendala (Darmalaksana et al., 2020). Jadwal kuliah semester IV kelas A hari Senin pukul 10.2012.00 WIB., sedangkan jadwal kuliah Semester IV kelas B hari Rabu pukul 10.20-12.00 WIB.

Mata kuliah ini telah menyiapkan RPKPS (Rencana Program dan Kegiatan Pembelajaran Semester) sebagai perencanaan (planning) untuk proses pembelajaran selama satu semester (Darmalaksana, 2020d). Mata kuliah ini juga telah menyiapkan panduan untuk pelaksanaan latihan menulis proposal (Darmalaksana, 2020a), latihan mini research, latihan penulisan artikel ilmiah hasil penelitian (Darmalaksana, 2020c), dan latihan pengiriman naskah artikel ke jurnal ilmiah (Darmalaksana \& Suryana, 2018). RPKPS disiapkan sebagai materi kontrak belajar, di dalamnya tertuang ekspektasi pembelajaran. 
Khazanah Pendidikan Islam, Vol. 2 No. 3: 114-125

Ekspektasi Pembelajaran Berbasis Kurikulum: Studi Kasus Pengajaran Mata Kuliah Metode Penelitian Pada Program Studi Ilmu Hadis

Wahyudin Darmalaksana

Adapun panduan kuliah disiapkan sebagai alat "interogasi" pencapaian hasil latihan mahasiswa (Org, 2019).

Pelaksanaan kuliah non tatap muka dibuat ketentuan, yakni absensi awal serta pengumpulan hasil latihan pekan lalu 5 (lima) menit, pembahasan bahan kajian 10 (sepuluh) menit, sesi interaktif 20 (dua puluh) menit, penyampaian materi pekan depan 5 (lima) menit, sesi instruksi kerja penugasan atau latihan 5 (lima) menit, dan absensi akhir serta lanjutan pengumpulan hasil latihan pekan lalu 5 (lima) menit. Perkuliahan ini juga telah menerapkan proses feedback (umpan balik) terhadap hasil tahapan latihan mahasiswa. Interaksi dilakukan melalui WhatsApp, baik grup maupun personal melalui saluran pribadi (Darmalaksana, 2020n). Hasil latihan mahasiswa setiap tahapannya dikirim melalui email yang kemudian dilakukaan telaah terhadap konten untuk memastikan peningkatan kualitas, sejak awal memulai penulisan hingga akhir penulisan. Proses feedback ini diakui oleh kalangan ahli dunia pendidikan sebagai strategi yang tepat dalam memacu motivasi dan peningkatan kualitas (Org, 2019).

Sebanyak 62\% mahasiswa telah mampu melaksanakan latihan sesuai dengan manual yang telah disedikan. Secara umum mahasiswa talah sampai pada penyelesaian proposal penelitian dan beberapa telah menunjukan kemajuan dalam penulisan artikel hasil penelitian. Adanya sebuah manual untuk acuan mahasiswa merupakan subjek yang seharusnya dalam dunia pendidikan agar mahasiswa dapat belajar mandiri melalui peer-review (telaah antar-sebaya) dalam memosisikan mahasiswa sebagai pusat (He et al., 2019). Seluruh proses perkuliahan telah dibukukan, baik kompilasi proposal (Qintan et al., 2020) maupun rekam jejak perkuliahan (Darmalaksana, 2020k).

Pada akhir perkuliahan dilaksanakan UAS secara online, sedangkan materi UAS, yakni: 1) Bagaimana menentukan tujuan penelitian; 2) Bagaimana menentukan rumusan masalah; 3) Bagaimana mengurai pertanyaan penelitian; 4) Bagaimana melakukan pencarian referensi; 5) Bagaimana melakukan tinjauan pustka; 6) Bagaimana membuat kerangka berpikir; 7) Bagaimana melakukan pengutipan (sitasi) terhadap rujukan (referensi) dengan menggunakan aplikasi references; 8) Bagaimana menentukan metode penelitian; 9) Bagaimana menyusun sistematika penulisan; 10) Bagaimana menampilkan data hasil penelitian; 11) Bagaimana membahas dan menganalisis data penelitian; dan 12) Bagaimana menyimpulkan hasil pembahasan penelitian. Jawaban UAS diarahkan agar sesuai dengan bahan kajian atau panduan yang telah disediakan yang dapat diakses di Blog Spot dan terdapat pula di repositori. Arahan ini dimaksudkan untuk mengukur tingkat penguasaan pengetahuan terhadap panduan atau manual latihan. Materi UAS termasuk pengiriman proposal penelitian hasil tahapan latihan untuk penilaian kesesuaiannya dengan manual latihan dan penilaian kedalaman konten serta kerapihan penulisan. Materi UAS termasuk juga pengiriman kemajuan penulisan artikel hasil mini penelitian (mini research).

Materi UAS diarahkan agar dikirim dalam 1 (satu) file MS. Word dengan mencantumkan Nama, NIM, dan Kelas. Materi UAS diunggah pada e-Knows, aplikasi resmi e-learning UIN Sunan Gunung Djati Bandung, paling lambat, Senin, 13 Juli 2020 untuk Kelas A dan Rabu, 15 Juli 2020 untuk Kelas B. Semester IV Kelas A dari 35 berhasil login e-Knows 30 Orang dan tidak berhasil login 5 Orang. Semester IV Kelas B dari 40 berhasil login e-Knows 28 Orang dan tidak berhasil login 12 Orang. Daftar mahasiswa yang belum berhasil login e-Knows disampaikan kepada admin untuk aktifasi akun dan diarahkan untuk mengirim materi UAS ke email.

Pengisian nilai pada portal Salam (Sistem Layanan Administrasi Mahasiswa) dilaksanakan Kamis, 23 Juli 2020. Salam adalah aplikasi portal akademik mahasiswa UIN Sunan Gunung Djati Bandung. Sebelumnya, hari Selasa, 21 Juli 2020 diumumkan nilai sementara melalui Grup WhatsApp dengan tujuan memberikan waktu kepada mahasiswa yang masih nilai B terutama C untuk melakukan perbaikan. 
Khazanah Pendidikan Islam, Vol. 2 No. 3: 114-125

Ekspektasi Pembelajaran Berbasis Kurikulum: Studi Kasus Pengajaran Mata Kuliah Metode Penelitian Pada Program Studi Ilmu Hadis

Wahyudin Darmalaksana

Bahkan, setelah input nilai pada portal Salam masih diberi waktu 1 pekan sebagai masa sanggah bila memungkinkan dilakukan perbaikan nilai. Kenyataannya, dari 75 Mahasiswa terdapat 17 Orang yang nilai B (22\%), dan 11 Orang nilai C (14\%). Meskipun dengan diperolehnya 47 Orang nilai A (62\%) dari 75 Mahasiswa maka dapat dipandang proses pekuliahan mencapai keberhasilan. Pada dasarnya relatif tidak terdapat kendala pada proses pekuliahan. Memang perkuliahan model online yang terpaksa akbibat kondisi Covid-19 dapat dipahami sebagai kendala (Darmalaksana, 2020k), namun sekaligus juga tantangan karena pendidikan tinggi pada abad 21 sudah seharusnya menerapkan pembelajaran $e$ learning (He et al., 2019).

Secara keseluruhan proses pembelajaran mata kuliah Metode Penelitian telah dilakukan evalusi. Pelaksanaan mata kuliah ini dinilai telah sesuai dan bahkan melampaui ekspektasi. Namun masih terdapat masalah-masalah kasuistik beban perkuliahan yang dihadapi oleh mahasiswa. Meskipun bersifat kasuistik tetap saja hal tersebut perlu mendapat perhatian dengan tanpa menghambat kepentingan mahasiswa yang lebih umum. Umpamanya, mahasiswa sangat telat mengumpulkan materi UAS maka tidak bisa ditunggu sampai batas waktu tertentu karena terbentur masa input nilai yang dilaksanakan secara serentak di tingkat fakultas. Ekspektasi mata kuliah ini dibuat melampaui sasaran pencapaian akreditasi nasional, hal ini dimaksudkan untuk mengejar target keunggulan (excellence) sejalan dengan agenda PTKI menuju WCU (Muqoyyidin, 2016).

\section{SIMPULAN}

Pencapaian ekspektasi pembelajaran berbasis kurikulum terstandar menentukan keunggulan pendidikan tinggi. Mewujudkan hal ini menuntut penyusunan visi, misi, tujuan, rencana pembelajaran, proses pembelajaran, capaiaan mata kuliah, dan evaluasi pembelajaran. Paling utama sekali adalah kerja keras melampaui ekspektasi untuk pencapaian keunggulan. Penelitian ini diharapkan memiliki implikasi manfaat khususnya bagi para pengampu mata kuliah dalam penyusunan ekspektasi pembelajaran dan kerja keras untuk melampauinya bagi pencapaian keunggulan. Penelitian ini memiliki keterbatasan hanya studi kasus pada mata kuliah tertentu, sehingg diperlukan penelitian lebih luas pada mata kuliah bidang lain. Penelitian ini merekomendasikan pentingnya penyusunan kurikulum dengan ekspektasi yang terstandar dalam rangka mewujudkan keunggulan pendidikan tinggi di tingkat nasional menuju keunggulan di level internasional.

\section{DAFTAR PUSTAKA}

Aprilia, W. (2020). Organisasi dan Desain Pengembangan Kurikulum. ISLAMIKA, 2(2), 208-226.

Awaliyah, R., \& Darmalaksana, W. (2020). Perempuan Meminang Laki-Laki Menurut Hadis. Jurnal Perspektif, 4(1), 28-37.

Darmalaksana, W. (n.d.). Bimbingan Teknis Penelitian.

Darmalaksana, W. (2019). Penyusunan Proposal Penelitian.

Darmalaksana, W. (2020a). Cara Menulis Proposal Penelitian. Fakultas Ushuluddin UIN Sunan Gunung Djati Bandung.

Darmalaksana, W. (2020b). Formula Penelitian Pengalaman Kelas Menulis. Jurnal Kelas Menulis UIN Sunan Gunung Djati Bandung.

Darmalaksana, W. (2020c). Hasil dan Pembahasan untuk Artikel Konseptual. Jurnal Kelas Menulis Fakultas Ushuluddin, 1(5), 1-7. 
Khazanah Pendidikan Islam, Vol. 2 No. 3: 114-125

Ekspektasi Pembelajaran Berbasis Kurikulum: Studi Kasus Pengajaran Mata Kuliah Metode Penelitian Pada Program Studi Ilmu Hadis

Wahyudin Darmalaksana

Darmalaksana, W. (2020d). Implementasi RPKPS Mata Kuliah Metode Penelitian Berbasis OBE pada SKL dan CPL Jenjang Sarjana Prodi Ilmu Hadis. Jurnal Ushuluddin UIN Sunan Gunung Djati Bandung, 1-16.

Darmalaksana, W. (2020e). Kelas Menulis: Analisis Capaian Latihan Efektif. Fakultas Ushuluddin UIN Sunan Gunung Djati Bandung.

Darmalaksana, W. (2020f). Kelas Menulis: Artikel Ilmiah Capaian Mata Kuliah. Fakultas Ushuluddin UIN Sunan Gunung Djati Bandung.

Darmalaksana, W. (2020g). Kelas menulis: Dari proposal penelitian ke artikel ilmiah, publikasi jurnal, dan hak kekayaan intelektual. Sentra Publikasi Indonesia.

Darmalaksana, W. (2020h). Latihan Menulis Latar Belakang Masalah.

Darmalaksana, W. (2020i). Login and Submission of Article: A Guide to Academic Writing Practice Classes. Jurnal Kelas Menulis UIN Sunan Gunung Djati Bandung, 1.

Darmalaksana, W. (2020j). Metode Penelitian Kualitatif Studi Pustaka dan Studi Lapangan. PrePrint Digital Library UIN Sunan Gunung Djati Bandung.

Darmalaksana, W. (2020k). Rekam Proses Kuliah Online: METODE PENELITIAN. Fakultas Ushuluddin UIN Sunan Gunung Djati Bandung.

Darmalaksana, W. (2020l). Sitasi Ilmiah Menggunakan Perangkat References pada Microsoft Word. Jurnal Kelas Menulis UIN Sunan Gunung Djati Bandung, 1.

Darmalaksana, W. (2020m). Studi Penggunaan Analisis Pendekatan Ilmu-ilmu Sosial dalam Penelitian Hadis Metode Syarah. Khazanah Sosial, 2(3), 155-166.

Darmalaksana, W. (2020n). WhatsApp Kuliah Mobile. Fakultas Ushuluddin UIN Sunan Gunung Djati Bandung.

Darmalaksana, W. (2020o). Yuk Gabung Kelas Menulis! Latihan Efektif Kelas Menulis Fakultas Ushuluddin UIN Sunan Gunung Djati Bandung.

Darmalaksana, W., Hambali, R., Masrur, A., \& Muhlas, M. (2020). Analisis Pembelajaran Online Masa WFH Pandemic Covid-19 sebagai Tantangan Pemimpin Digital Abad 21. Karya Tulis Ilmiah (KTI) Masa Work From Home (WFH) Covid-19 UIN Sunan Gunung Djati Bandung, 1-12.

Darmalaksana, W., \& Suryana, Y. (2018). Korespondensi dalam publikasi ilmiah. Jurnal Perspektif, $1(2)$.

Fachriansyah, K., \& Sulastri, E. (2020). Developing Legal-Entity Higher Education Institution (Perguruan Tinggi Negeri-Badan Hukum) as Centre of Excellence. Bappenas Working Papers, 3(2), 199-217.

Fadillah, F. J. (2019). Kurikulum Pendidikan.

He, W., Xu, G., \& Kruck, S. E. (2019). Online IS education for the 21st century. Journal of Information Systems Education, 25(2), 1.

Herianto, H. (2020). Telaah Kurikulum 2013: Hasil Revisi Tahun 2018.

Istikaroh, A. (2020). Sistem Manajemen Mutu Perguruan Tinggi Berbasis Asean University Network Quallity Assurance (Aun-Qa) Di Universitas Islam Negeri Sunan Kalijaga Yogyakarta. IAIN.

Istislami, Y. (2020). Permasalahan Mutu Pendidikan Indonesia. Jurnal Lentera (Jurnal Pendidikan Dan Pengajaran Bahasa Indonesia), 3(2), 276-283.

Muqoyyidin, A. W. (2016). Menuju World-Class Research University Berbasis Khazanah Pesantren Sebagai Distingsi Pendidikan Tinggi Islam di Era Globalisasi. Pesantren Management and Development towards Globalization.

Org, A. (2019). The process of essay writing in a literature course: the student's views and the tutor's feedback. Estonian Journal of Education/Eesti Haridusteaduste Ajakiri, 7(2).

Penyusun, T. (2018a). Buku Panduan Penyusunan Kurikulum Pendidikan Tinggi. Direktorat Jenderal Pembelajaran dan Kemahasiswaan Kementerian Riset Teknologi dan Pendidikan Tinggi.

Penyusun, T. (2018b). Panduan Pengembangan Kurikulum PTKI Mengacu pada KKNI dan SN-Dikti. Direktorat Pendidikan Tinggi Keagamaan Islam Direktorat Jenderal Pendidikan Islam Kementerian Agama Republik Indonesia. 
Khazanah Pendidikan Islam, Vol. 2 No. 3: 114-125

Ekspektasi Pembelajaran Berbasis Kurikulum: Studi Kasus Pengajaran Mata Kuliah Metode Penelitian

Pada Program Studi Ilmu Hadis

Wahyudin Darmalaksana

Penyusun, T. (2020). Profil Lulusan Jurusan Ilmu Hadis. Jurusan Ilmu Hadis Fakultas Ushuluddin UIN Sunan Gunung Djati Bandung.

Qintan, A., Mardiana, D., Dilawati, R., Krismayani, I., Safitri, S. D., \& Asma, D. A. I. (2020). Kelas Menulis: Kompilasi Proposal Untuk Pelaksanaan Penelitian Menuju Publikasi Artikel Jurnal Ilmiah. Fakultas Ushuluddin UIN Sunan Gunung Djati Bandung.

Rizky, R. D. (2019). Optimalisasi Fasilitas Gedung 2 Fakultas Teknik Untuk Mendukung Internasionalisasi UNS Menuju World Class University.

Susanti, N. (2020). Kebijakan Peningkatan Kualitas Pendidikan Di Indonesia. Al-Kahfi: Jurnal Pendidikan Agama Islam, 5(1), 128-141.

Telaumbanua, D. (2020). Urgensi Pembentukan Aturan Terkait Pencegahan Covid-19 di Indonesia. QALAMUNA: Jurnal Pendidikan, Sosial, Dan Agama, 12(01), 59-70. https://doi.org/10.37680/qalamuna.v12i01.290

Tim Penyusun. (2018). Keputusan Direktur Jenderal Pendidikan Islam Nomor 2500 Tahun 2018 tentang Standar Kompetensi Lulusan dan Capaian Pembelajaran Lulusan Program Studi Jenjang Sarjana pada PTKI. 